\title{
GMR
}

\section{Selection of cowpea progenies with enhanced drought-tolerance traits using principal component analysis}

\author{
C.C. Sousa ${ }^{1}$, K.J. Damasceno-Silva², E.A. Bastos ${ }^{2}$ and M.M. Rocha ${ }^{2}$ \\ ${ }^{1}$ Departamento de Ciências Naturais, Universidade Federal do Maranhão, \\ Campus Codó, Codó, MA, Brasil \\ ${ }^{2}$ Embrapa Meio-Norte, Avenida Duque de Caxias, Buenos Aires, Teresina, PI, Brasil \\ Corresponding author: K.J. Damasceno-Silva \\ E-mail: kaesel.damasceno@embrapa.br \\ Genet. Mol. Res. 14 (4): 15981-15987 (2015) \\ Received August 18, 2015 \\ Accepted October 2, 2015 \\ Published December 7, 2015 \\ DOI http://dx.doi.org/10.4238/2015.December.7.10
}

ABSTRACT. Vigna unguiculata (L.) Walp (cowpea) is a food crop with high nutritional value that is cultivated throughout tropical and subtropical regions of the world. The main constraint on high productivity of cowpea is water deficit, caused by the long periods of drought that occur in these regions. The aim of the present study was to select elite cowpea genotypes with enhanced drought tolerance, by applying principal component analysis to 219 first-cycle progenies obtained in a recurrent selection program. The experimental design comprised a simple $15 \times 15$ lattice with 450 plots, each of two rows of 10 plants. Plants were grown under water-deficit conditions by applying a water depth of $205 \mathrm{~mm}$ representing one-half of that required by cowpea. Variables assessed were flowering, maturation, pod length, number and mass of beans/pod, mass of 100 beans, and productivity/plot. Ten elite cowpea genotypes were selected, in which principal components 1 and 2 encompassed variables related to yield (pod length, beans/pod, and productivity/plot) and life precocity (flowering and maturation), respectively.

Key words: Vigna unguiculata; Drought tolerance; Recurrent selection; Cowpea; Multivariate analysis 


\section{INTRODUCTION}

The leguminous plant Vigna unguiculata (L.) Walp. (Fabaceae), commonly known as the cowpea or feijão-caupi in Brazil, is cultivated as a food crop throughout tropical and subtropical regions of the world. Cowpea seeds exhibit excellent nutritional quality by virtue of their high carbohydrate, protein, fat, iron, and zinc contents, and they contain all amino acids essential to the human diet (Olalekan and Bosede, 2010; Mamiro et al., 2011). Furthermore, although the cowpea is somewhat underutilized in the promotion of health, the flour can be employed as a food supplement to control chronic diseases, such as diabetes and hypercholesterolemia (Seererama et al., 2012).

Although the global annual yield of cowpea exceeds 5 million tons, average productivity remains low (472.66 kg/ha), owing mainly to abiotic environmental factors, particularly drought stress (Belko et al., 2012).

One of the most cost-effective strategies in combating the effects of water deficiency in plants is the development of cultivars with improved drought resistance (Rauf, 2008). Considerable progress has been made breeding plants with traits related to water stress, based on advances in the areas of plant physiology, molecular genetics, and molecular biology (Cattivelli et al., 2008).

Studies focusing on the physiology of adaptation have provided new insights into the mechanisms of drought tolerance in plants. An investigation of the response of rice (Oryza sativa) to water deficiency revealed that the most tolerant genotypes exhibit reduced osmotic potential, deeper root growth, and grains with superior antioxidant capacity (Ji et al., 2012). Ganjeali et al. (2011) showed that drought tolerance in chickpea (Cicer arietinum) was correlated with reduced transpiration and smaller leaf area, whereas tolerance to water deficit in cowpea was reportedly associated with increased membrane stability, diminished stomata opening, reduced transpiration, and smaller leaf area (Labuschagne et al., 2008; Belko et al., 2012).

In the field of molecular genetics, one strategy for identifying genomic regions associated with drought resistance is mapping of quantitative trait loci (QTL) in plants exposed to water limiting conditions. Examples of this approach include studies conducted on common wheat (Kumar et al., 2012), barley (Varshney et al., 2012), and maize (Zhu et al., 2011).

A number of candidate genes for the control of drought tolerance have been identified and utilized in transgenic experiments. For example, Li et al. (2011) reported that insertion of the wheat expansin gene TaEXPB23 into tobacco (Nicotiana tabacum) resulted in transgenic plants with reduced and slower water loss. Furthermore, Wang et al. (2011) reported that expression of the gene encoding arginine decarboxylase from Poncirus trifoliata (PtADC) in transgenic tobacco plants resulted in enhanced tolerance to water deficit. Muchero et al. (2010) mapped candidate genes associated with drought tolerance of cowpea, and identified seven restriction fragment length polymorfism (RFLP) markers that may assist in assessment of this trait in cowpea seedlings.

Clearly, various approaches may be employed in improving drought tolerance of cowpea cultivars that already present good agronomical characteristics and high yields, and these would provide economic benefits for small- and large-scale producers alike. However, in order to achieve genetic improvement, it is essential that genetic variability exist within a species (Mutava et al., 2011). One plant breeding method that allows frequency of alleles associated with target traits to increase, while conserving genetic variability of the population, is recurrent selection. This method was initially proposed for allogamous plants, and it has been employed in this context for the genetic improvement of various target traits. Furthermore, the method has also been applied successfully to autogamous crops such as rice (Rangel et al., 2002), tomato (Avdikos et al., 2011), and soybean (Zhao et al., 2007). 
A recurrent selection program involves three main steps, namely, establishment of the base population, selection of progenies with desirable phenotypes, and inter-crossing of superior progenies. Selection of appropriate progenies may be performed with the aid of univariate or multivariate statistical tools. When a large number of desirable traits are involved, the application of principal component analysis (PCA) is recommended to facilitate selection of the most relevant variables.

The aim of the present study was to select elite cowpea genotypes with enhanced tolerance to water deficit, by applying PCA techniques to progenies obtained in the first cycle of a recurrent selection program.

\section{MATERIAL AND METHODS}

All tests were carried out in the experimental area of Embrapa Meio-Norte (Teresina, PI, Brazil) located $05^{\circ} 05^{\prime} 05^{\prime \prime S}$ : $42^{\circ} 47^{\prime} 05^{\prime \prime} \mathrm{W}$, at an altitude of $72 \mathrm{~m}$. Experiments were conducted between August 8 and October 302011 , during which period the average temperature was $29.6^{\circ} \mathrm{C}$ (range $21.7^{\circ}$ to $37.9^{\circ} \mathrm{C}$ ); average air humidity was $48 \%$ (range 23 to $80 \%$ ), and there was no precipitation during the period.

Tolerance to water deficit was evaluated in 225 genotypes comprising 219 first-cycle cowpea progenies, obtained in a recurrent selection program, together with the six parental cultivars (considered drought tolerant). The experimental design comprised a simple $15 \times 15$ lattice that included 450 plots, each consisting of two rows of 10 plants (20 plants/plot). Plots measured $1.4 \times 3.0 \mathrm{~m}$, spacing between rows was $0.70 \mathrm{~m}$, and the spacing between plants within a row was $0.30 \mathrm{~m}$. Water-deficit conditions were simulated by applying a water depth of $205 \mathrm{~mm}$, which represented one half of the water requirements of cowpea.

Target variables were flowering (days), maturation (days), pod length $(\mathrm{cm})$, number of beans/pod, mass of beans/pod $(\mathrm{g})$, mass of 100 beans $(\mathrm{g})$, and productivity/plot $(\mathrm{g})$. In order to select cowpea progenies with enhanced tolerance to water deficit for the continuing recurrent selection program, analysis of intra-block variance of the lattice and PCA were performed with the aid of the statistical software program SAS version 9.0 (SAS Institute, Cary, NC, USA).

\section{RESULTS}

Outcomes of analysis of intra-block variance are shown in Table 1. Progenies were significantly different $(P \leq 0.05)$ with respect to all variables with the exception of number of beans/ pod. Table 2 presents a summary of PCA and displays eigenvalues, the cumulative percent of variance accounted for by the principal components (PCs), and the eigenvectors estimated based on the averages of each of the seven variables. According to the Kaiser (1960) criterion, only PCs with eigenvalues greater than 1 should be retained. Therefore, PCs 1 and 2 were selected (Table 1). These accounted for, respectively, 39.26 and $22.34 \%$ of the variability of the progenies and, taken together, $61.60 \%$ of the total diversity. Characteristics that contributed most to variability in PC1 were pod length, number of beans/pod and productivity/plot (collectively termed the production components); while in PC2, flowering and maturation (referred to collectively as precocity components) were the largest contributors to variability.

In the discriminant analysis biplot of PC1 and PC2, shown in Figure 1, genotypes presenting high yields but long developmental cycles under conditions of water deficit are included in quadrant 1. These progenies, and especially genotypes $15,121,122$, and 210 , could be of interest from a productivity point of view, despite their non-precocious cycles. Quadrant 2 comprises the drought- 
susceptible genotypes exhibiting low yields and long developmental cycles, whereas quadrant 3 contains progenies with precocious cycles but low yields under water limiting conditions. None of the progenies within these two quadrants would be suitable for the recurrent selection program due to their substandard productivity. The ten progenies encompassed by quadrant 4 (genotypes 20, 33, 37, $47,49,58,60,88,129$, and 198) together with the control genotype BRS Paraguaçu (221), are those that exhibited high yield with short flowering cycle and precocious maturity despite the conditions of water deficit. Characteristics of these ten elite progenies and control are displayed in Table 3.

Table 1. Inter-block analysis of variables assessed in a recurrent selection program for drought-tolerant cowpea progenies, using a simple $15 \times 15$ lattice design.

\begin{tabular}{|c|c|c|c|c|c|c|c|c|}
\hline \multirow[t]{2}{*}{ Source of variation } & \multirow[t]{2}{*}{ d.f. } & \multicolumn{7}{|c|}{ Means of squares } \\
\hline & & $\begin{array}{l}\text { Flowering } \\
\text { (days) }\end{array}$ & $\begin{array}{l}\text { Maturation } \\
\text { (days) }\end{array}$ & $\begin{array}{l}\text { Pod length } \\
(\mathrm{cm})\end{array}$ & $\begin{array}{l}\text { Number of } \\
\text { beans/pod }\end{array}$ & $\begin{array}{c}\text { Mass of } \\
\text { beans/pod (g) }\end{array}$ & $\begin{array}{c}\text { Mass of } \\
100 \text { beans }(\mathrm{g})\end{array}$ & Productivity/plot (g) \\
\hline Progenies & 178 & $15.99^{*}$ & $6.57^{\star}$ & $3.98^{*}$ & $6.07^{\mathrm{ns}}$ & $0.42^{*}$ & $14.61^{*}$ & $0.28^{*}$ \\
\hline Plots & 28 & 16.36 & 7.51 & 4.67 & 6.70 & 0.54 & 15.66 & 0.40 \\
\hline Repetitions & 1 & 57.85 & 41.93 & 33.15 & 41.32 & 0.65 & 44.62 & 4.25 \\
\hline Error & 54 & 10.02 & 4.41 & 2.50 & 5.29 & 0.27 & 7.76 & 0.19 \\
\hline Total & 261 & 16.92 & 11.87 & 4.45 & 6.65 & 0.42 & 14.16 & 0.33 \\
\hline Coefficient of variance & & 6.91 & 3.03 & 8.68 & 23.59 & 26.17 & 13.67 & 28.92 \\
\hline Mean & & 45.00 & 63.56 & 18.24 & 9.74 & 2.00 & 20.00 & 62.56 \\
\hline
\end{tabular}

*Statistically significant at $5 \%$ probability; ${ }^{\text {ns }}$ not significant; d.f. = degrees of freedom.

\begin{tabular}{|c|c|c|c|c|c|c|c|c|c|}
\hline PCs & Eigenvalues & $\begin{array}{c}\text { Cumulative percentage } \\
\text { of variance }\end{array}$ & $\begin{array}{l}\text { Flowering } \\
\text { (days) }\end{array}$ & $\begin{array}{l}\text { Maturation } \\
\text { (days) }\end{array}$ & $\begin{array}{l}\text { Pod length } \\
\qquad(\mathrm{cm})\end{array}$ & $\begin{array}{l}\text { Number of } \\
\text { beans/pod }\end{array}$ & $\begin{array}{c}\text { Mass of } \\
\text { beans/pod (g) }\end{array}$ & $\begin{array}{c}\text { Mass of } \\
100 \text { beans }(\mathrm{g})\end{array}$ & $\begin{array}{l}\text { Productivity/ } \\
\text { plot }(\mathrm{g})\end{array}$ \\
\hline PC1 & 2.75 & 0.3926 & -0.27 & -0.24 & 0.47 & 0.47 & 0.39 & 0.30 & 0.43 \\
\hline PC2 & 1.56 & 0.6160 & 0.59 & 0.58 & 0.24 & 0.26 & 0.25 & 0.24 & -0.25 \\
\hline PC3 & 0.93 & 0.7491 & -0.23 & 0.17 & -0.38 & -0.40 & 0.27 & 0.74 & 0.03 \\
\hline PC4 & 0.62 & 0.8372 & -0.07 & 0.42 & 0.14 & 0.03 & -0.70 & 0.21 & 0.51 \\
\hline PC5 & 0.50 & 0.9093 & 0.02 & 0.40 & -0.22 & -0.18 & 0.46 & -0.48 & 0.57 \\
\hline PC6 & 0.39 & 0.9646 & 0.79 & -0.49 & -0.17 & -0.12 & -0.05 & 0.19 & 0.41 \\
\hline PC7 & 0.25 & 1.0000 & 0.04 & -0.03 & 0.70 & -0.71 & 0.06 & -0.03 & -0.01 \\
\hline
\end{tabular}

$\mathrm{PC}=$ principal component
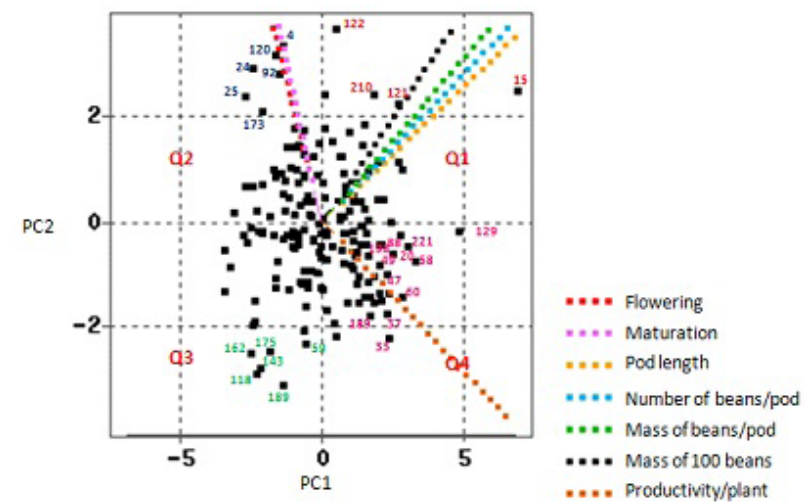

Figure 1. Principal component analysis biplot. $P C 1$ and $P C 2$ refer to eigenvectors relating to production $(\mathrm{g})$ and precocity (days), respectively. PC, principal component; $\mathrm{Q}$, quadrant. 
Table 3. Means of squares for variables related to selected, elite cowpea progenies and control genotype BRS Paraguaçu (221).

\begin{tabular}{|c|c|c|c|c|c|c|c|}
\hline \multirow[t]{2}{*}{ Progeny } & \multicolumn{7}{|c|}{ Means of squares } \\
\hline & $\begin{array}{c}\text { Flowering } \\
\text { (days) }\end{array}$ & $\begin{array}{l}\text { Maturation } \\
\text { (days) }\end{array}$ & $\begin{array}{l}\text { Pod length } \\
(\mathrm{cm})\end{array}$ & $\begin{array}{l}\text { Number of } \\
\text { beans/pod }\end{array}$ & $\begin{array}{c}\text { Mass of } \\
\text { beans/pod (g) }\end{array}$ & $\begin{array}{c}\text { Mass of } \\
100 \text { beans }(\mathrm{g})\end{array}$ & $\begin{array}{l}\text { Productivity/ } \\
\text { plot (g) }\end{array}$ \\
\hline 20 & 43 & 63 & 20.7 & 11.7 & 2.6 & 20.6 & 188.0 \\
\hline 33 & 42 & 61 & 21.1 & 8.4 & 1.9 & 19.8 & 274.8 \\
\hline 37 & 42 & 60 & 19.4 & 10.0 & 2.3 & 22.4 & 189.4 \\
\hline 47 & 42 & 63 & 10.1 & 11.7 & 2.5 & 21.0 & 201.8 \\
\hline 49 & 42 & 63 & 18.8 & 12.0 & 2.4 & 21.6 & 165.3 \\
\hline 58 & 42 & 62 & 22.7 & 12.3 & 2.5 & 20.3 & 196.7 \\
\hline 60 & 41 & 61 & 19.9 & 11.3 & 2.7 & 22.2 & 200.0 \\
\hline 88 & 43 & 63 & 19.2 & 12.7 & 2.7 & 20.9 & 143.5 \\
\hline 129 & 44 & 63 & 22.0 & 14.7 & 3.4 & 23.0 & 316.8 \\
\hline 198 & 44 & 61 & 18.7 & 13.0 & 2.6 & 20.1 & 93.5 \\
\hline 221 (control) & 44 & 60 & 20.8 & 14.7 & 3.0 & 20.5 & 133.3 \\
\hline
\end{tabular}

\section{DISCUSSION}

According to Abayomi and Abidoye (2009), water deficit delays flowering in cowpea crops. This was evident in the present study, in which flowering of some progenies occurred only after 59 days. With regard to maturation, however, it is of interest to note that 20 of the progenies in our study exhibited precocious maturity, possibly as a result of water deficit. In this context, Verslues et al. (2006) hypothesized that plants develop strategies to escape the effects of drought stress through, for example, rapid development and early completion of the life cycle before water limitation causes physiological damage.

In the present study, mean pod length of the cowpea progenies was low, with some pods presenting a small and shriveled appearance, possibly as a consequence of water limitation.

Water deficit had no significant influence on the mean number of beans/pod, suggesting that this trait may not represent a valuable marker for the selection of drought-tolerant genotypes. On the other hand, Ahmed and Suliman (2010) reported that water deficit significantly reduced the mean number of beans/pod in a cowpea cultivar and in two local genotypes, suggesting that this variable is a sensitive indicator of drought tolerance.

The observed mean mass of $2.0 \mathrm{~g}$ for beans/pod was considerably lower than the average value reported in the literature. This divergence may be explained by the less harsh conditions employed in experiments conducted by Rodrigues (2012). Regarding the mass of 100 beans, mean values in cowpeas cultivated under full water supply were significantly higher than those in cowpeas exposed to water limiting conditions (Bastos et al., 2011). Results from the present study confirmed that drought stress exerts a negative influence on cowpea productivity, as has been previously reported (Uarrota, 2010; Bastos et al., 2011; Nascimento et al., 2011).

In an earlier evaluation of 47 cowpea genotypes by PCA, Bertini et al. (2010) determined eigenvalues of $39.88,24.21$, and $16.23 \%$ for PC1, PC2, and PC3, respectively. In that investigation, PC1 encompassed eigenvectors relating to yield, while PC2 included those associated with precocity, as was also the case in the present study. Furthermore, in the work of Bertini et al. (2010), the trait with the highest weight in PC1 was pod length, which is also consistent with the findings of the present study.

Selective breeding is a technique that allows plant breeders to select for groups of several desirable traits, to produce varieties with superior agronomic characteristics. Within this 
context, the progenies of quadrant 1 of the PCA biplot (Figure 1) retained high productivity under conditions of water deficiency but did not exhibit short developmental cycles and, hence, would not represent the best option for selection of elite cowpea lines. Progenies of quadrant 2 combined the most undesirable characteristics of low-yield and long developmental cycle, traits that have been recognized as typical of genotypes with low tolerance to water deficiency (Nascimento et al., 2011). Progenies of quadrant 3, presenting precocious cycles, had the disadvantage of being low-yielding, hence were not chosen for the continuing recurrent selection program. Quadrant 4 brought together the characteristics of high-yield and precocious development, and encompassed all of the progenies presenting desirable traits within PC1 and PC2.

Genetic improvement of cowpea, with respect to drought and heat tolerance, requires fixation into a single genotype of alleles associated with tolerance, along with those associated with agronomical secondary traits such as duration of developmental cycle (Hall, 2004). In this study, the application of PCA to first-cycle cowpea progenies allowed for selection of 10 elite genotypes with all of the required characteristics for the continuation of a drought-tolerant recurrent selection program.

Improvement of drought tolerance in cowpea, through the application of a recurrent selection program, depends on traits being inherited in a quantitative manner. Such programs comprise three or more selection cycles conducted in a repetitive manner, such that selection of progenies with enhanced drought tolerance must commence at the first cycle in order to permit future selections. Application of PCA to 219 first-cycle cowpea progenies produced a first principal component that encompassed eigenvectors relating to yield (pod length, beans/pod and productivity/ plot), and a second principal component that included eigenvectors relating to precocity (flowering and maturation). From this analysis, 10 elite genotypes could be selected with all the required characteristics for the continuation of a drought-tolerant recurrent selection program.

\section{Conflicts of interest}

The authors declare no conflict of interest

\section{ACKNOWLEDGMENTS}

The authors thank the National Council for Scientific and Technological Development (CNPq - Process \#485350/2013-0) and the Embrapa Mid-North for financial support and the National Council for the Improvement of Higher Education (CAPES) for the scholarship.

\section{REFERENCES}

Abayomi YA and Abidoye TO (2009). Evaluation of cowpea genotypes for soil moisture stress tolerance under screen house conditions. Afr. J. Plant Sci. 3: 229-237.

Ahmed FE and Suliman AS (2010). Effect of water stress applied at different stages of growth on seed yield and water-use efficiency of cowpea. Agric. Biol. J. N. Am. 1: 534-540.

Avdikos ID, Tsivelika N, Gallidou A, Koutsika-Sotiriou M, et al. (2011). Exploitation of heterosis through recurrent selection scheme applied in segregating generations of a tomato breeding program. Sci. Hortic. 130: 701-707.

Bastos EA, Nascimento SP, Silva EM, Freire Filho FR, et al. (2011). Identification of cowpea genotypes for drought tolerance. Rev. Cienc. Agron. 42: 100-107.

Belko N, Zaman-Allah M, Diop NN, Cisse N, et al. (2012). Restriction of transpiration rate under high vapour pressure deficit and non-limiting water conditions is important for terminal drought tolerance in cowpea. Plant Biol. 15: 304-316.

Bertini CHCM, Almeida WS, Silva APM, Lima JW, et al. (2010). Análise multivariada e índice de seleção na identificação de 
genótipos superiores de feijão-caupi. Acta Sci. 32: 613-619.

Cattivelli L, Rizza F, Badeck FW, Mazzucotelli E, et al. (2008). Drought tolerance improvement in crop plants: An integrated view from breeding to genomics. Field Crop Res. 105: 1-14.

Ganjeali A, Porsa H and Bagheri A (2011). Assessment of Iranian chickpea (Cicer arietinum L.) germplasms for drought tolerance. Agr. Water Manage. 98: 1477-1484.

Hall AE (2004). Breeding for adaptation to drought and heat in cowpea. Eur. J. Agron. 21: 447-454.

Ji K, Wang Y, Sun W, Lou Q, et al. (2012). Drought-responsive mechanisms in rice genotypes with contrasting drought tolerance during reproductive stage. J. Plant Physiol. 169: 336-344.

Kaiser HF (1960). The application of electronic computers to factor analysis. Educ. Psychol. Meas. 20: 141-151.

Kumar S, Seghal S, Kumar U, Prasad PVV, et al. (2012). Genomic characterization of drought tolerance-related traits in spring wheat. Euphytica 186: 265-276.

Labuschagne MT, Verhoeven R and Nkouanessi N (2008). Drought tolerance assessment of African cowpea accessions based on stomatal behaviour and cell membrane stability. J. Agr. Sci. 146: 689-694.

Li F, Xing S, Guo Q, Zhao M, et al. (2011). Drought tolerance through over-expression of the expansin gene TaEXPB23 in transgenic tobacco. J. Plant Physiol. 168: 960-966.

Mamiro PS, Mbwaga AM, Mamiro DP, Mwanri AW, et al. (2011). Nutritional quality and utilization of local and improved cowpea varieties in some regions in Tanzania. Afr. J. Food Agr. Nutr. Dev. 11: 4490-4506.

Muchero W, Ehlers JD and Roberts PA (2010). Restriction site polymorphism-based candidate gene mapping for seedling drought tolerance in cowpea [Vigna unguiculata (L.) Walp.]. Theor. Appl. Genet. 120: 509-518.

Mutava RN, Prasada PVV, Tuinstrab MR, Kofoidc KD, et al. (2011). Characterization of sorghum genotypes for traits related to drought tolerance. Field Crop Res. 123: 10-18.

Nascimento SP, Bastos EA, Araújo ECE, Freire Filho FR, et al. (2011). Tolerância ao déficit hídrico em genótipos de feijãocaupi. Rev. Bras. Eng. Agric. Ambient. 15: 853-860.

Olalekan AJ and Bosede BF (2010). Comparative study on chemical composition and functional properties of three Nigerian legumes (jack beans, pigeon pea and cowpea). J. Emerg. Trends Eng. Appl. Sci. 1: 89-95.

Rangel PHN, Moraes OP and Zimmermann FJP (2002). Grain yield gains in three recurrent selection cycles in the CAN-IRAT 4 irrigated rice population. Crop Breed. Appl. Biotechnol. 2: 369-374.

Rauf S (2008). Breeding sunflower (Helianthus annuus L.) for drought tolerance. Commun. Biometry Crop Sci. 3: $29-44$.

Richey FD (1950). Corn breeding. Adv. Genet. 3: 159-192.

Rodrigues EV (2012). Obtenção de população base em programa de seleção recorrente para tolerância ao déficit hídrico em feijão-caupi. Master thesis, UFPI, Teresina.

Seererama YN, Sashikala VB and Pratape VM (2012). Phenolic compounds in cowpea and horse gram flours in comparison to chickpea flour: Evaluation of their antioxidant and enzyme inhibitory properties associated with hyperglycemia and hypertension. Food Chem. 133: 156-162.

Uarrota VG (2010). Response of cowpea (Vigna unguiculata L. Walp.) to water stress and phosphorus fertilization. J. Agron. 9: 87-91.

Varshney RK, Paulob RK, Grandod S, Van Eeuwijk FA, et al. (2012). Genome wide association analyses for drought tolerance related traits in barley (Hordeum vulgare L.). Field Crop Res. 126: 171-180.

Verslues PE, Agarwal M, Katiyar-Agarwal S, Zhu J, et al. (2006). Methods and concepts in quantifying resistance to drought, salt and freezing, abiotic stresses that affect plant water status. Plant J. 45: 523-539.

Wang BQ, Zhang QF, Liu JH and Li GH (2011). Overexpression of PtADC confers enhanced dehydration and drought tolerance in transgenic tobacco and tomato: Effect on ROS elimination. Biochem. Biophys. Res. Commun. 413: 10-16.

Zhao S, Zhang M, Jiang C, Yang C, et al. (2007). Study on quality improvement effect and separate character of soybean male sterile (MS1) recurrent selection population. Agric. Sci. China 6: 545-551.

Zhu JJ, Wang XP, Sun CX, Zhu XM, et al. (2011). Mapping of QTL associated with drought tolerance in a semi-automobile rain shelter in maize (Zea mays L.). Agric. Sci. China 10: 987-999. 